\title{
Evaluation of Basic Safety Training with CIPP
}

\author{
DarulPrayogo $^{\text {a }}$, Rusdarti ${ }^{\mathrm{b}}$, Tri Joko Raharjo ${ }^{\mathrm{c}}$, AsihKuswardinah $^{\mathrm{d}}$ \\ aStudent,Educational Management,Universitas Negeri Semarang, Indonesia \\ darulprayogo@students.unnes.ac.id \\ bProfessor,Educational Management, Universitas Negeri Semarang, Indonesia \\ rusdarti@mail.unnes.ac.id \\ cProfessor,Educational Management, Universitas Negeri Semarang, Indonesia \\ trijokoraharjo@mail.unnes.ac.id \\ d Doctor,Educational Management, Universitas Negeri Semarang, Indonesia \\ Asih@mail.unnes.ac.id
}

\begin{abstract}
This examination intends to research the effect of context, input, process, and products (CIPP) on instruction and administrations of Basic Safety Training (BST) at the PoliteknikIlmuPelayaran (PIP) Semarang. The examination is Research and Development by using the ex post facto approach. The exploration area is at the PoliteknikIlmuPelayaran (PIP) Semarang with an entire population of 50 individuals and an example of 50. The exploration information was gathered utilizing a poll strategy and afterward broke down utilizing evaluative investigation strategies through clear quantitative examination. The outcomes discovered $82.00 \%$ setting assessment, $70.00 \%$ info assessment, $96.00 \%$ cycle assessment, and $82.00 \%$ item assessment. CIPP additionally infers that every one of the viewpoints embraced were in acceptable classifications for schooling and preparing administrations of Basic Safety Training at the PoliteknikIlmuPelayaran (PIP).
\end{abstract}

Keywords:Evaluation, Service, Basic Safety Training, CIPP.

\section{Introduction}

Ship transportation has an advantage on the representatives who are functioning as team. The Baltic and International Maritime Council (Bimco) express that in 2020 the world required 1,593,198 sailors. Nonetheless, there were just $1,555,281$ sailors, so it ought to be 37,917 more. It is a chance for the individuals who wish to work on board dispatches, as the oceans extend to more employment opportunity opening than ashore (Kamis et al., 2020). Basic Safety Training (BST) ought to be one of the base instructions and preparing programs that planned seafarer should follow. The program means to give preparing members comprehension and abilities about the rudiments of security ready. They should likewise have the option to rehearse the information to forestall and beat crises while cruising.

PoliteknikIlmuPelayaran (PIP) Semarang is an instructive establishment under the Ministry of Transportation. The grounds organize instruction and preparing administrations of Basic Safety Training (BST) for the overall population who need to fill in as sailors. The primary target of the preparation is to reinforce the member's abilities, so they are skilled to play out a salvage in a crisis condition. They should have the option to forestall fires and douse them. Plus, they are relied upon to comprehend different crises, word related wellbeing and security, light clinical consideration ready, and self-salvage. Members are likewise needed to participate in forestalling marine contamination and create social correspondence on board the ship.

At the underlying field perceptions and meetings with schooling and preparing supervisors, the specialists discovered numerous inadequacies in the instruction and preparing administrations of Basic Safety Training program at the PoliteknikIlmuPelayaran (PIP) Semarang. One of these inadequacies is the timetable of instructing and learning exercises in the study hall and field practice, which are masterminded in an unstructured and methodical way. One timetable regularly crashes into another because of conflicting exercise times. The issue is shown because of the predetermined number of instructors and lacking offices.

Different discoveries show that the arranging, execution, and assessment of schooling and preparing are not readied dependent on administration standards, so the execution is less powerful. From the consequences of the meeting with the Head of the Seafarers' Education and Training Unit, the learning centers around passing on information verbally, it has not yet arrived at the phase of allowing preparing members the chance to build up their own experiences and judgment when they face basic circumstances (Warju, 2016). That implies the speaker or educator doesn't consider their own learning techniques.

The CIPP assessment model offers a more perplexing application since it covers both developmental and 
summative assessments. The consequences of the unique circumstance, info, cycle, and item assessment will be helpful in deciding (developmental) and make responsible data (summative). Thus, it will add more different vital choices applied by establishments in directing instructive projects. Two CIPP assessment results register a customary tally of $91,000 \%$ and a computational check of $91.600 \%$ (Hakan \& Seval, 2011). In view of the investigation, the Computer-Assisted CIPP assessment model can figure more rapidly and precisely than traditional, albeit the thing that matters isn't huge. Consequently, further exact exploration is expected to talk about the discussion.

Student wellbeing preparing is advantageous to lessen the danger of a work injury that may happen whenever and anyplace. Subsequently, every ship's group is needed to join security preparing. In the discoveries of the adequacy of Basic Safety Training on security, wellbeing preparing is solid in the cruising scene. Nonetheless, it should be upheld by proper learning techniques and models with the goal that they can without much of a stretch practice it while working. With the help of innovation, learning gets simpler and builds the preparation member proficiency to comprehend the material.

In the assessment of adjustment of Basic Safety Training as a reaction to a catastrophe, it shows that this preparation has demonstrated to assume a fundamental part in open mindfulness, and it is recommended to improve it. Networks experienced Basic Safety Training has demonstrated to be more ready and responsive in managing catastrophes. Context, Input, Process, and Product (CIPP) is an Information Service Evaluation Model. It is the response to tackle issues in the assessment of administrations. The CIPP assessment model was planned because of the educator's absence of perception in evaluating the instructing cycle (Asfaroh et al., 2017). This is the reason the achievement pace of data administrations in schools unable be examined plainly. Additionally, the assessment technique's incapability likewise brings about powerless school responsibility and deficient improvement or advancement. With CIPP, data administrations can be assessed exhaustively.

\section{LitreatureReview}

\section{A. Management of Education and Training}

Hussin et al., (2012) uncovers that administration is a cycle of shaping collaboration in a gathering, which later makes a shared objective. Then, Finney (2020) states that administration is the correspondence of different assets created from the arranging, sorting out, and controlling cycles to accomplish certain aims. In view of these thoughts, the board is characterized as a cycle for tackling issues with successful strategies to accomplish authoritative objectives and targets by utilizing existing assets productively. The board comprises of numerous angles like control, coordination, inspiration, plan cycles, advancement, and the impact of hierarchical objectives and assets in accomplishing objectives (Ismail et al., 2019).

Nguyen (2020) contend that administration is the way toward guiding gatherings to accomplish authoritative objectives by and large. Managerial specialists, for example, Sergiovanni, Coombs, and Thurson likewise have a comparative slant by underscoring that administration is the way toward working with and through others to achieve authoritative objectives productively (Ghosh \& Rubly, 2017).

Based on the information over, the specialists plan that administration destinations consistently talk about certain viewpoints, including a) collaboration, b) led by at least two individuals, and c) accomplishing shared objectives (Jensen et al., 2020). Along these lines, the board is a cycle including numerous individuals successfully and proficiently to achieve hierarchical purposes. The board in an association capacity as an endeavor to do certain exercises, so its primary targets are accomplished beneficially and effectively.

\section{B. Basic Safety Training}

This abilities instruction and preparing expect to guarantee that members have essential competency and security abilities while cruising. Members should exhibit a progression of salvage in a crisis as one marker of those abilities (Bolaños et al., 2016). They have the competency to forestall fires just as to quench them. The members are additionally expected to comprehend a few kinds of crises, word related wellbeing, and security (K3).

Aside from the markers above, there are different focuses like clinical consideration abilities, self-salvage during a crisis, forestalling marine contamination, and keeping up friendly correspondence ready. This Basic Safety Training likewise accentuates the members to appreciate the fundamental information on security and practice it to forestall and defeat issues while cruising. Appropriately, preparing members are not just capable in principle, so are the professionals as well.

\section{WorkFlow(Methodolody)}

From the Literature review we have understood the need for research in this wide areas and transforming 
thesame into real world scenario the need for alternative method is very much important at this point of time. Theplacement of U-turns at successive junctions and rotary junctions at various places which are required is the needofthehournow

This investigation is evaluative exploration with quantitative-elucidating examination. The examination populace is all preparation coordinators adding up to 50 individuals so that all have a place with the populace research. The information was gathered through surveys and meetings. Before the survey was submitted to the respondent, the instrument was through the legitimacy and dependability stages. Legitimate information in the legitimacy test results can be utilized for research (Hair et al., 2014). Two things of information were discovered to be invalid during the legitimacy test. Unwavering quality test utilizing Cronbach shows setting 0.807, input 0.815, and item 0.907. Likewise, all CIPP parts were additionally dependable with a Cronbach Alpha worth more prominent than 0.60 .

To break down the information, the scientists utilized unmistakable factual techniques. The strategy is then joined with the CIPP to assess the execution of the distance learning program at the PoliteknikIlmuPelayaran (PIP) Semarang. The following stage is choosing the schooling and preparing model through the Planning, Implementation, and Control way to deal with decide the suitable model for the PoliteknikIlmuPelayaran (PIP) Semarang and might be valuable as a preparation improvement methodology.

This examination means to get a solid image of the Basic Safety Training execution through the Context, Input, Process, and Product (CIPP) approach (Umam \& Saripah, 2018). The advancement research likewise reports in detail the conduct of preparing members, preparing exercises, and investigation to decide the appropriate strategy and improvement. The interaction additionally uses the Context, Input, Process, and Product (CIPP) parts. After the occasion is altogether perceived, the subsequent stage is investigating the examination subject to check the general circumstance in regular day to day existence.

Stufflebeam (2007) who is an administration master, underscores that policymakers should decide. The setting in CIPP implies leading exploration dependent on requirements, issues, and freedoms to decide the objective, and guarantee the nature of graduates. Information assumes a part in arranging and coordination in expanding HR. The cycle prompts the execution of preparation, and the item serves to distinguish and survey its viability (Stufflebeam \& Zhang, 2017).

\section{AnalysisAndResults}

Each institution and preparing coordinator should comprehend the assessment segments containing all the information about the preparation. The training will make it simpler for coordinators to make learning materials and a preparation air coordinated as the destinations. The depiction of every assessment part is introduced in Table1.

Table 1. The Description of Education and Training Services Evaluated with the CiPP Model

\begin{tabular}{lr|r|r|r|r} 
& $\mathrm{N}$ & \multicolumn{1}{c}{ Minimum } & \multicolumn{1}{c}{ Maximum } & Mean & Std. Deviation \\
\hline CONTEXT & 50 & 37,00 & 64,00 & 51,7800 & 5,70460 \\
\hline INPUT & 50 & 31,00 & 50,00 & 39,8800 & 4,15339 \\
\hline PROCESS & 50 & 74,00 & 104,00 & 81,8000 & 7,16853 \\
\hline PRODUCT & 50 & 107,00 & 160,00 & 122,1200 & 9,21543 \\
\hline Valid N (listwise) & 50 & & & & \\
\hline
\end{tabular}

Source: Processed Primary Data, 2020.

Based on the data in Table 1 above, the evaluation of management training using CIPP is as follows: The Context component produces a mean of 51.7800, with a standard deviation of 5.70450. The input component shows a mean of 39.8800 , with a standard deviation of 4.15339 . The Process component gets a mean of 81.8000 , with a standard deviation of 7.16853. The Product component finds a mean of 122.1200 with a standard deviation of 9.21543. The detailed description of each component is provided below.

\section{A. Evaluation of Training Organizers based on Context Components.}

Context evaluation reflects the initial conditions of a program. The data was the result of interviews, questionnaires, and documentation. Organizers were required to acquire all the initial knowledge and understanding available in the context components. Hence, training materials are more specific and easier to 
achieve the objectives.

Descriptive analysis of the management of Basic Safety Training taken from the input point of view presents the highest score of 64 points and the lowest of 37 points. Meanwhile, the mean is 51.7800 with a standard deviation (SDi) of 5.70460. The description of each context component is explained in Figure 1 below.

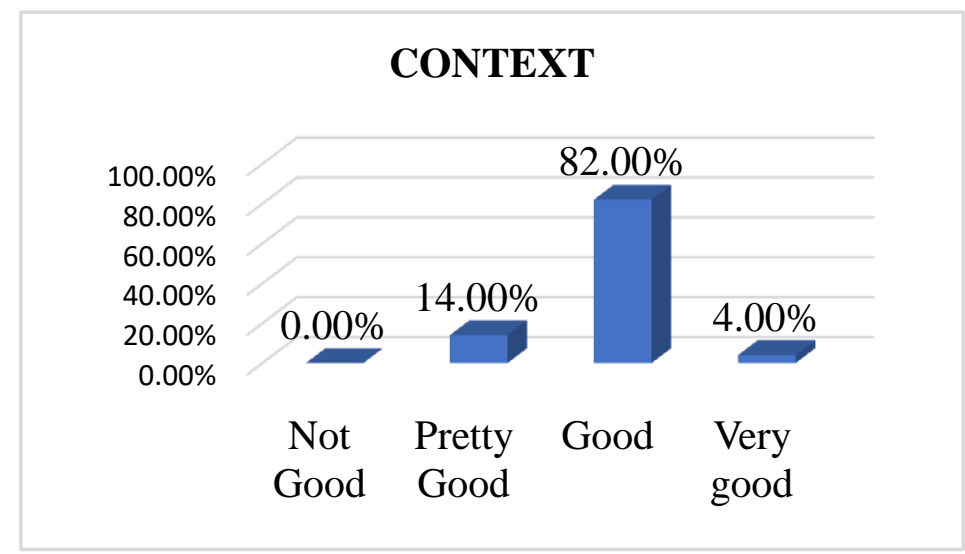

Figure 1. The Description of Context Component

Source: Processed primary data, 2020.

The figure above indicates the respondents confirmed that $4.00 \%$ of initial knowledge and understanding of the organizers were in the very good category. Those who said good were $82.00 \%$, and the organizers who stated that they had a fairly good understanding were $14.00 \%$. Most of the organizers had good knowledge and understanding of training evaluation of $82.00 \%$. Therefore, in terms of the context component, the understanding and knowledge of BST organizers at the PoliteknikIlmuPelayaran (PIP) Semarang are in a good category.

\section{B. Evaluation of Education and Training Organizers based on Input Components}

The next evaluation is input, which emphasizes the assessment of program planning. The data were collected from interviews, questionnaires, and documentation. The input component in the training consists of planning, training participant requirements, schedules, and requirements for lecturers/instructors. It focuses on the implementation of education and training to become more structured and systematic, so the main objectives of the training are achieved completely.

Descriptive analysis of BST management for education and training managers, based on the input aspect, gets the highest input score of 50 points and the lowest of 31 points. The mean for the results of this descriptive analysis is 39.8800 and the Standard Deviation (SDi) is 4.15339. Each description of the components of the context is presented in Figure 2 below.

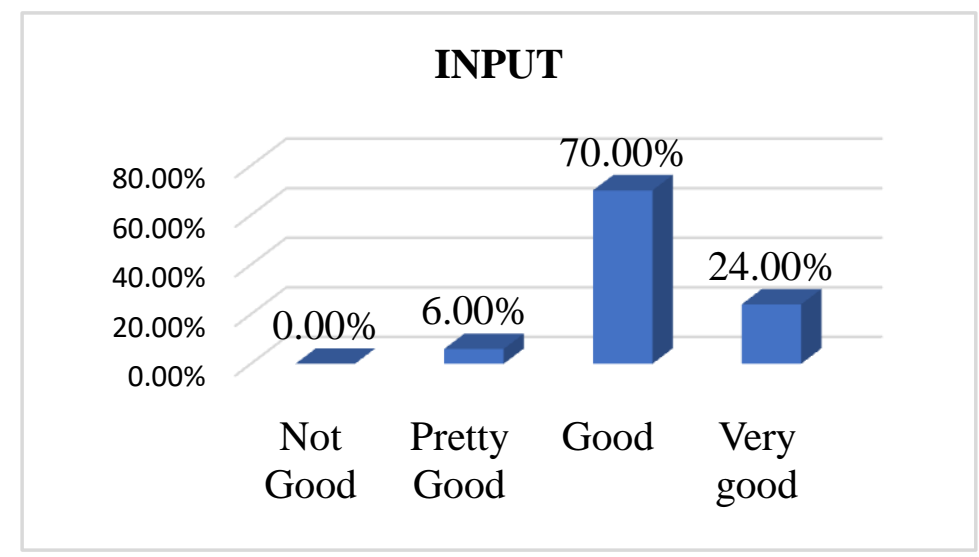

Figure 2. The Description of Input Component

Source: Processed primary data, 2020 
Figure 2 above shows the initial conditions in the implementation of BST training were in the very good category of $24.00 \%$, the good category of $70.00 \%$, and the organizers of the training stated that they had a fairly good understanding was $6.00 \%$. Based on the results of the descriptive analysis, most of the training organizers who had good evaluation knowledge and understanding were $70.00 \%$. Therefore, the initial ability of BST training organizers at the PoliteknikIlmuPelayaran (PIP) Semarang is in the good category.

\section{Evaluation of Education and Training Organizers based on Process Components}

In the process phase, the evaluation was conducted while the training activities were in progress. The data were collected from interviews, questionnaires, and documentation. The process components include the implementation of plans and documentation of activities regarding the ongoing process. Evaluation of this process must be implemented, so the training runs in a structured and systematic manner and the main objectives of the training are achieved perfectly.

Descriptive analysis of BST management from a process point of view found that the highest score is 74 points, and the lowest is 50 points. The mean of the descriptive analysis results is 81.8000 with a standard deviation (SDi) of 7.16853. Detailed descriptions of the process components are shown in Figure 3 below.

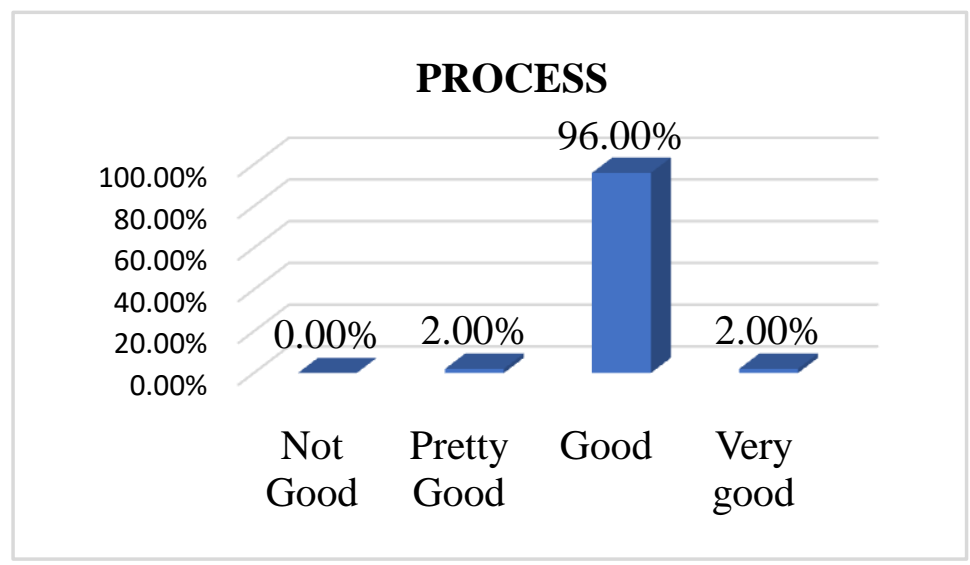

Figure 3. The Description of Process Component Source: Processed primary data, 2020

Figure 3 above reveals the $2.00 \%$ respondents stated that the initial conditions for organizing the training were in the very good category, $96.00 \%$ said the condition was good, and the training organizers who stated that they had a fairly good understanding was $2.00 \%$. From the results of the descriptive analysis, most of the education and training organizers were classified as good at $70.00 \%$. Hence, the planning run well and programs were executed excellently.

\section{Evaluation of Training Organizers based on Product Components}

Product evaluation is an assessment of the ongoing education and training program activities. The evaluation sees how far the targets are achieved. The data collected was based on the results of interviews, questionnaires, and organizer documentation. The product component in this training is an evaluation of the planning and documentation after the program was completed.

Descriptive analysis of BST management gets the highest score of 160 and the lowest of 107 . The mean was 122.1200 with a standard deviation (SDi) of 9.21543. The description of each process component is described in Figure 4 below. 


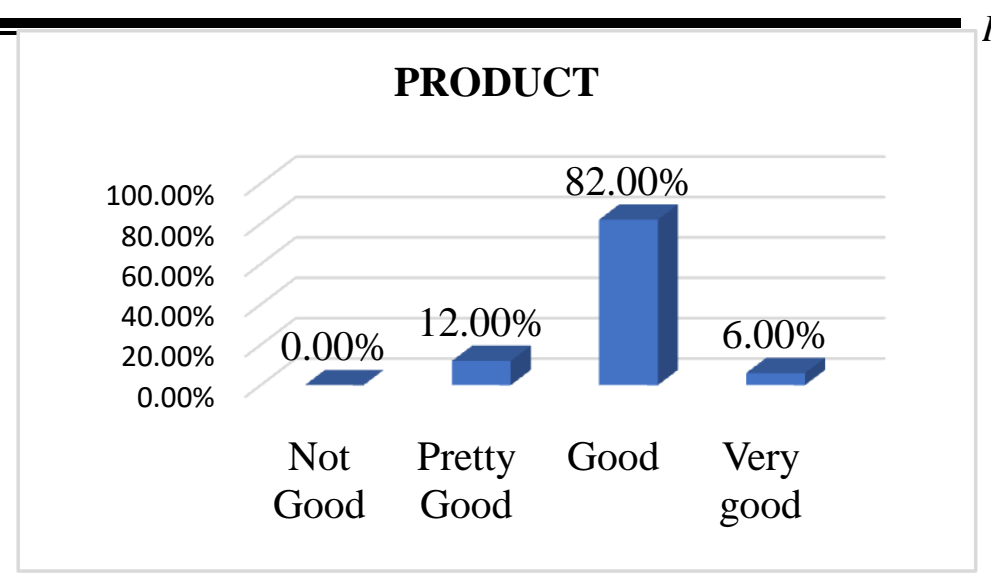

Figure 4. The Description of Product Component Source: Processed primary data, 2020

Figure 4 above indicates that the $6.00 \%$. respondents commented the initial conditions for the implementation of BST were in the very good category, $82.00 \%$ stated it was good, and the organizers stated that they had a fairly good understanding was $12.00 \%$. Based on these results, some training organizers got $70.00 \%$ points or in the good category. Therefore, the planning was realized well and the program was carried out properly.

\section{Conclusions}

The research and discussion results conclude that the Basic Safety Training (BST) implemented at the PoliteknikIlmuPelayaran (PIP) Semarang using the CIPP model is in a good category. The mean score for the context component is 82.00 , which means good. It conveys the initial understanding and knowledge of BST organizers are good. The mean score for the input component is 70.00 , which means good. The planning was executed properly, and the program objectives run well. The average score for the process component is 96.00 , so it was well defined because the planning was successfully carried out, and the implementation was as expected. The average score of product components is 82.00 , and it is also quite good. It is because the planning was correlated, and the training organizers conducted it well. Overall, the implementation of BST at the PoliteknikIlmuPelayaran (PIP) Semarang using the CIPP model is good.

\section{References}

1. Asfaroh, J. A., Rosana, D., \& Supahar. (2017). Development of CIPP Model of Evaluation Instrument on the Implementation of Project Assessment in Science Learning. International Journal Of Environmental \& Science Education.

2. Bolaños, E. K., Boone, J. R. M., Lauresta, E. V. M., \& Calinao, J. R. G. (2016). Effectiveness of Basic Safety Training As Perceived By Filipino Seafarers. Laguna Journal of International Tourism and Hospitality Management.

3. Finney, T. L. (2020). Confirmative Evaluation: New CIPP Evaluation Model. Journal of Modern Applied Statistical Methods. https://doi.org/10.22237/jmasm/1598889893

4. Ghosh, S., \& Rubly, C. (2017). Seafarers' perceptions of training towards compliance with the ballast water management (BWM) convention. Australian Journal of Maritime and Ocean Affairs. https://doi.org/10.1080/18366503.2017.1326092

5. Hair, J. F., Black, W. C., Babin, B. J., \& Anderson, R. E. (2014). Multivariate Data Analysis Seventh Edition. In Pearson New International. https://doi.org/10.1007/978-3-319-01517-0_3

6. Hakan, K., \& Seval, F. (2011). CIPP evaluation model scale: Development, reliability and validity. Procedia - Social and Behavioral Sciences. https://doi.org/10.1016/j.sbspro.2011.03.146

7. Hussin, M. F., Wang, B., \& Hipnie, R. (2012). The reliability and validity of Basic Offshore Safety and Emergency Training knowledge test. Journal of King Saud University - Engineering Sciences. https://doi.org/10.1016/j.jksues.2011.05.002

8. Ismail, A., Foboy, N. A., Mohamad Nor, A., Abdullah, A. A., \& Ismail, Y. (2019). Training 
Management As An Antecedent Of Training Transfer. Journal of Nusantara Studies (JONUS). https://doi.org/10.24200/jonus.vol4iss1pp136-158

9. Jensen, H. J., Jensen, H. J., \& Oldenburg, M. (2020). Training seafarers to deal with multicultural crew members and stress on board. International Maritime Health. https://doi.org/10.5603/IMH.2020.0031

10. Kamis, A. S., Fuad, A. F. A., Saadon, M. S. I., \& Fadzil, M. N. (2020). The Impact Of Basic Training On Seafarers' Safety Knowledge, Attitude And Behaviour. Journal of Sustainability Science and Management. https://doi.org/10.46754/jssm.2020.08.012

11. Nguyen, A. (2020). In-Service Training Management-A Case Study in Vietnam. International Education Studies. https://doi.org/10.5539/ies.v13n10p1

12. Stufflebeam, D. L. (2007). CIPP Evaluation Checklist..

13. Stufflebeam, D. L., \& Zhang, G. (2017). The CIPP Evaluation Model: How to Evaluate for Improvement and Accountability. In The CIPP Evaluation Model: How to Evaluate for Improvement and Accountability.

14. Umam, K. A., \& Saripah, I. (2018). Using the Context, Input, Process and Product (CIPP) Model in the Evaluation of Training Programs. International Journal of Pedagogy and Teacher Education. https://doi.org/10.20961/ijpte.v2i0.26086

15. Warju, W. (2016). Educational Program Evaluation using CIPP Model. Innovation of Vocational Technology Education. https://doi.org/10.17509/invotec.v12i1.4502 